\title{
Так с Севера ли к нам приходит свет? Does the Light Come to Us from the North?
}

\author{
Денис Кондаков \\ Полоцкий государственный университет \\ d.kandakou@psu.by \\ Denis Kondakov \\ Polotsk State University \\ d.kandakou@psu.by
}

Рецензия на книгу: Alexandre Stroev, La Russie et la France des Lumières : Monarques et philosophes, écrivains et espions. Paris: Institut d'études slaves (Bibliothèque russe de l'Institut d'études slaves, tome CXXXVI), 2017. $512 \mathrm{p}$.

Review of Alexandre Stroev, La Russie et la France des Lumières: Monarques et philosophes, écrivains et espions. Paris: Institut d'études slaves (Bibliothèque russe de l'Institut d'études slaves, tome CXXXVI), 2017. 512 p.

Александр Фёдорович Строев - один из немногих филологов, которые осваивают terra incognita литературы XVIII века: утопические сочинения, несбыточные политические и экономические проекты, химерические технические изобретения, поддельные письма знаменитых людей, апокрифы. В своей новаторской книге Те, кто поправляют Фортуну: авантюристы Просвещения, вышедшей в 1997 году, он дал новое определение той знаменитой армии франкоязычных авантюристов, которая колесила по дорогам Европы. А. Ф.Строев превратил их из второстепенных персонажей литературной сцены во влиятельных культурных посредников, безуспешно пытавшихся изменить Российскую империю при помощи своих текстов и преуспевших в распространении идей и практик Просвещения, установлении диалога между Россией и Западом. В своей новой книге Россия и Франция в эпоху Просвещения: монархи и философы, писатели и шпионы исследователь представляет плоды долгих и кропотливых поисков в библиотеках и архивах России и Франции, Бельгии и Швейцарии, Великобритании и Ватикана. Ее героями выступают великие французские авторы и анонимные сочинители, ученые и фантазеры, блестящие политики и рядовые дипломатические агенты. Всех их объединяет одна страсть - Россия, которую они желают восславить или дискредитировать, соблазнить или подчинить, понять или отвергнуть.

Как отмечает сам автор в предисловии, тексты, которые его привлекают, имеют гибридную жанровую природу. Их можно было бы считать художественными творениями, если бы они не были изначально наделены прагматической функцией, которая сближает их с политическими, юридическими, частными документами. Это значит, что готового инструментария для их изучения нет, его необходимо вырабатывать специально. А. Ф. Строев комбинирует подходы различных дисциплин. Для сугубо филологического анализа он применяет приемы генетической критики, которые позволяют не только воссоздавать процесс возникновения того или иного 
произведения, но и выполнять главную для исследователя задачу - обнаруживать подделки и фальшивки и выявлять их источники, устанавливать авторство анонимных произведений. Так, А. Ф. Строев, полемизируя с Теодором Бестерманом и Фредериком Делофром, доказывает, что "Ода. Польским конфедератам," приложенная к письму Вольтера Екатерине II от 12 февраля 1772 года, принадлежит перу самого фернейского патриарха. Исследователь приводит новые убедительные доказательства тому, что Новый Дедал (Nouveau Dédale, 1742) написан Жан-Жаком Руссо, а Письма о сочинении, озаглавленном "Жизнь генерала Дюмурье" (Lettres sur l'ouvrage intitulé La Vie du Gen. Dumourier avec une carte de la forêt d'Argonne, 1795) - Габриэлем Сенаком де Мейяном. А.Ф.Строев сравнивает автографы писем принца Шарля де Линя к русским корреспондентам с их поздними, "отредактированными" самим автором копиями и разоблачает политику "переписывания" австрийского политика и военачальника.

Затем эти ценные открытия помещаются в более широкий теоретический контекст. Его можно уместить в одну фразу: жизнь подражает литературе. Мнимая простота этой формулы, восходящей к трудам Ю.М. Лотмана о русской культуре XVIII-XIX веков, скрывает множество трудностей. Прежде всего, существует опасность переоценить значимость литературных моделей и подчинить им живую жизнь. ${ }^{1}$ А.Ф. Строев сознательно уходит от этого соблазна, искусно сочетая литературоведческую интерпретацию текста с анализом исторических документов, конструируя кольцевую модель взаимодействия между вымыслом и фактом, не отдавая пальму первенства ни тому, ни другому. Утопические и приключенческие романы, панегирические стихотворения, философские трактаты эпохи Просвещения задают образцы политического и социального поведения, предлагают экономические и научные модели, превращающиеся в своего рода пророчества. Осуществив их, но придав при этом новую форму, культура возвращает их впоследствии в мир вымысла.

Исследования конкретных случаев, приведенные в книге, ярко иллюстрируют этот тезис. Так, сказка госпожи д’Онуа Остров блаженства оказывается претекстом депеш шевалье Дугласа-Маккензи, дипломатического представителя Франции при дворе Елизаветы Петровны. Письма Вольтера к Екатерине II содержат множество политических проектов футуристического толка. А.Ф. Строев так описывает механизм сотворения нового мира в высочайшей переписке: "Вольтер предлагает цели, к которым должна стремиться страна под управлением мудрой императрицы, и изображает их уже достигнутыми. Утопия, положенная на бумагу, требует своего воплощения в жизнь" (с. 196). Есть в книге и примеры обратного свойства. В 1790-е годы стремление Сенака де Мейяна стать историографом Екатерины II и ее державы разбивается о сопротивление императрицы, но писатель творчески использует свою неудачу, "превращая жизнь в сентиментальный роман" (353) и позднее торгует этим жизненным вымыслом, дабы получить вспомоществование от российского двора в начале XIX века.

Характеризуя методологию, использованную А. Ф.Строевым, мы затронули иллюстрирующие ее примеры, а потому самое время перейти к фактуре исследования. Текст книги разделен на три части, а их главные темы соответствуют трем формам

\footnotetext{
' Основные критические замечания в отношении семиотической концепции Лотмана касались именно этой проблемы. См. например, J. Breuillard, "Le voyage philosophique de Nikolaj Karamzin," Cahiers slaves $\mathrm{N}^{\circ} 10$, Routes et chemins slaves (Paris: Université Paris-Sorbonne, 2008): 123-153; А.В. Чудинов, Жильбер Ромм и Павел Строганов: история необычного союза (Москва: НЛО, 2010), 281-5. (A.V. Chudinov, Zhil'ber Romm i Pavel Stroganov: istoriia neobychnogo soiuza (Moscow: NLO, 2010)).
} 
взаимодействия между культурами: путешествия, литературные диалоги, дипломатические контакты.

Первая часть "Путешествия и путешественники" открывается разделом под названием "Франция и Россия на ментальной карте эпохи Просвещения," которая задает тон всей работе. Читатель сразу найдет в ней интерпретацию двух крупнейших культурных мифов XVIII столетия, разные варианты которых будут рассматриваться в последующих главах. Первый из этих мифов изображает Россию варварской страной, населенной властными женщинами-воительницами (амазонками), краем, где правит непостоянная фортуна. Второй, напротив, рисует идиллию и характеризует Россию как прибежище наук и искусств, где просвещенный народ кует будущее человечества. Интерпретируя этот позитивный образ, А. Ф.Строев полемизирует с Альбертом Лортолари ${ }^{2}$ и доказывает: французские философы вовсе не обольщались "русским миражом," а создавали его сами, в дальнейшем же, как всякий миф, он воспроизводил себя сам. Автор также показывает, что два противоречащих друг другу представления - о России варварской и России просвещенной - вступали во взаимодействие, и из него рождалось то силовое поле, в котором возникала взаимная заинтересованность и внимание Запада и Севера.

Следующие разделы первой части посвящены изображению французскими авторами просторов Российской империи, в первую очередь Сибири. Этот край одновременно манит и пугает просвещенную Францию. Под пером аббатов Прево и Дюлорана Сибирь обретает идиллические черты, в произведениях маркиза де Сада признаки обретенного рая вольнодумцев, для ученых Бюффона и Байи она предстает новой Атлантидой. При этом литераторы поставляют идеи для ученых. Например, А. Ф. Строев показывает, как астроном Жан-Сильвен Байи становится пророком Вольтера и протеже Екатерины II. В 1771 году в поэтическом "Послании к императрице российской" фернейский патриарх провозглашает: "Так с Севера сегодня нам приходит свет" ("C'est du Nord aujourd'hui que nous vient la lumière"). Байи подхватывает фразу и буквально реализует ее посыл, объявляя находки останков доисторических животных в Сибири доказательством зарождения там человеческой цивилизации. И интерес ученого к России не остался ни без внимания, ни без благодарности со стороны российской императрицы. "Защита и прославление" Сибири становится темой еще одного раздела первой части - "Как Франция эпохи Просвещения изобрела Китай и Россию, и что за этим последовало." Маркиз д'Аржанс, Николя-Габриэль Клер, Пьер-Шарль Левек и многие их современники, интересовавшиеся Поднебесной, естественным образом обращали свои взоры и на приграничную Сибирь и таким образом организовывали многосторонний культурный диалог. Так же как и Сибирь, другие регионы Российской империи привлекали к себе внимание просвещенной Европы. Для нее славянские древности "изобрел" граф Ян Потоцкий, неутомимый путешественник, создававший одновременно для себя новую родину и новую идентичность.

Во второй части книги, озаглавленной "Просвещенная царица," собраны работы на "женскую" тематику. Они занимают почти половину тома, но говорить о диспропорции неуместно, ведь в XVIII веке Россия - прежде всего женское царство. Однако сначала речь идет не о российских правительницах, а о приключениях в России шевалье д’Эона, знаменитого "Дон Кихота в юбке" и "амазонки Просвещения." Остальные же разделы ожидаемо посвящены историческому персонажу, к которому А.

\footnotetext{
${ }^{2}$ A. Lortholary, Le mirage russe en France au XVIII siècle (Paris: Boivin \& Cie, Editions contemporaines, 1951).
} 
Ф. Строев откровенно неравнодушен - Екатерине II. ${ }^{3}$ Дело, конечно, не только и не столько в личной симпатии, а в том, что вокруг нее строятся многие мифологические сюжеты Просвещения. Она воплощает собой миф о матери народов, образ матушкигосударыни, который тщательно разрабатывает в переписке с Вольтером. Фернейский патриарх, напротив, предпочитает изображать ее в облике Афины Паллады, Минервы, сочетающей женское и мужское начала. Вольтеру вторит принц де Линь. После смерти философа он стремится занять его место и стать доверенным корреспондентом российской императрицы, наследуя его эпистолярную стратегию. Отсюда, как показывает А. Ф.Строев, происходит и его стремление представить Екатерину II в облике Аполлона с женским лицом, и его желание «подправить» этот лик после смерти императрицы, создавая фальшивые письма или переписывая на новый лад отправленные.

Еще одна важная ипостась Екатерины II, которая акцентируется во второй части книги, - быть распорядительницей увеселений, устроительницей забав. Почти все ее игровые начинания вдохновлены французскими образцами, как, например, воображаемое Общество невежд (Société des ignorants), созданное наподобие Благородного ордена Лантюрлю маркизы де Лаферте-Эмбо. Однако А. Ф. Строев справедливо представляет общественные забавы императрицы не как адаптацию на российской почве зарубежных культурных практик, а как свою игру по чужим канонам. Общество невежд и Эрмитажный кружок преследовали сразу несколько разнонаправленных целей: посрамить внутренних противников, привлечь новых союзников из числа иноземных дипломатов и с их помощью укрепить свою репутацию покровительницы наук и искусств. Все эти цели, как известно, были успешно достигнуты к 1789 году, но затем игра утратила смысл. Важно то, что созданные мифы пережили саму игру, как это случилось, например, и с мифом о франкоязычном поэте эпохи Просвещения, образованном скифе, несущем тот самый свет с Севера. Автор прослеживает его рождение в поэтических диалогах Вольтера с графом Андреем Петровичем Шуваловым и князем Александром Михайловичем Белосельским и последующее использование в обмене стихами принца де Линя с графами Федором Гаврииловичем Головкиным и Сергеем Семеновичем Уваровым, а также дочерью князя Белосельского Зинаидой Волконской.

Если в первых двух частях книги предлагается генетический анализ русской мифологии Просвещения, то в третьей части, "Война перьев," речь ведется о ее бытовании в политической и общественной жизни. Мифы создаются писателями, а работать с ним приходится дипломатам. Раз уж Россия наречена царством женщин, то ее следует "соблазнять и подкупать" (365-384). На богатом архивном материале А. Ф. Строев демонстрирует причины неудач французских дипломатов при петербургском дворе в 1760-1770-е годы. То, что не удается профессионалам политики, с успехом выполняют литераторы: "литературные таланты помогают создать в СанктПетербурге кружки и салоны на парижский манер и передать во Францию положительный образ России" (р. 412). Исследователь приводит новые сведения о миссии в российской столице Доминика Вивана Денона в 1773-1774 годах: секретарь французского посольства устанавливает тесные связи с графом Андреем Кирилловичем Разумовским, чтобы воздействовать через него на двор великого князя Павла Петровича и его жены Натальи Алексеевны. Граф Сегюр шагает еще выше:

\footnotetext{
${ }^{3}$ Напомним о знаковом издании переписки Вольтера и Екатерины II, подготовленном А.Ф. Строевым: Voltaire Catherine II. Correspondance 1763-1778 ; texte présenté et annoté par Alexandre Stroev (Paris: Non Lieu, 2006).
} 
полномочный посол Франции попадает в ближайшее окружение императрицы, восхваляет ее в переписке с женой и бароном Гримом, который, как ему известно, честно сообщает о содержании писем такого рода в Санкт-Петербург. Литературные уловки Сегюра приводят к намеченной цели - установлению торгового договора между Францией и Россией.

А. Ф. Строев доказывает также, что на войне перьев опубликованные сочинения имеют не меньшее значение, чем тайная личная или дипломатическая переписка. Исторические труды Вольтера и Клода Карломана Рюльера, Николя-Габриэля Клера и Пьера-Шарля Левека, Жана-Бенуа Шерера и Жака Лакомба не столько освещают прошлое, сколько подправляют, приукрашивают его. Они излагают альтернативную версию российской истории, отражают ожидания настоящего и предсказывают благоденствие в будущем. Эти же функции часто берут на себя и романы, рядящиеся в одежды исторических повествований или мемуаров. Таков Подложный Петр III, или Жизнь и приключения бунтовщика Емельяна Пугачева (Faux Pierre ou la Vie et les avantures (sic!) du rebelle Jemeljan Pugatschew d'après l'original russe, 1775), текст, выдающий себя за перевод с русского языка записок об истинных событиях 1773-1774 годов, но изобилующий романными клише. Анализ этой малоизвестной книги, а также ложных завещаний Петра I и Екатерины II позволяет исследователю еще раз подчеркнуть проницаемость границы между политическим проектом и утопическим романом, историческим очерком и художественным сочинением на историческую тему в пограничном пространстве литературы Просвещения. Этот акцент, что еще важнее, позволяет выйти за пределы привычных в определении политического пути России оппозиций "азиатская страна" - "европейская страна," "собственный путь" "образец для подражания." Вместо того, чтобы в который раз вернуться к ним и не найти ответа, А.Ф.Строев предлагает нам прочитать русскую мифологию Просвещения как альтернативную историю, отдельные элементы которой воплотятся в жизнь через полтора столетия.

Россия и Франция эпохи Просвещения - очень личная книга. Ее автор рассказывает нам прежде всего о тех писателях и политических деятелях, к которым он относится почти как к своим знакомым, в силу долгой и кропотливой работы с их рукописями (7). В этом заключается безусловная привлекательность исследования, но здесь же можно при желании усмотреть и определенную слабость. Большинство представленных в книге исторических персонажей, образов, текстов относятся к царствованию Екатерины II, тогда как времена Петра I и Елизаветы Петровны, также богатые любопытными путешественниками, писателями с повадками пророков, хитроумными дипломатами, освещены значительно скромнее. Но у нас нет желания превращать это наблюдение в упрек. Нельзя объять необъятное, и даже труд, способный вместить в себя всю мифологию, вряд ли может охватить весь долгий век Просвещения. Написанная ясным, точным, изысканным и остроумным языком, книга Александра Федоровича Строева добивается главного: она устанавливает честный диалог между Россией и Францией, прошлым и настоящим, фактом и вымыслом. 